\title{
Recent Advances in Microfluidics-Based Chromatography-A Mini Review
}

\author{
Bo Bao ${ }^{1}$, Zhichao Wang ${ }^{1}$, Dilantha Thushara ${ }^{2}$, Achini Liyanage ${ }^{2}$, Sanja Gunawardena ${ }^{2}$, Zaiyong Yang ${ }^{3}$ \\ and Shuangliang Zhao ${ }^{1,3, *}$ \\ 1 State Key Laboratory of Chemical Engineering and School of Chemical Engineering, \\ East China University of Science and Technology, Shanghai 200237, China; bbao@ecust.edu.cn (B.B.); \\ y45190413@mail.ecust.edu.cn (Z.W.) \\ 2 Department of Chemical and Process Engineering, University of Moratuwa, Moratuwa 10400, Sri Lanka; \\ thusharas@uom.lk (D.T.); achinil@uom.lk (A.L.); sanjag@uom.lk (S.G.) \\ 3 Guangxi Key Laboratory of Petrochemical Resource Processing and Process Intensification Technology and \\ School of Chemistry and Chemical Engineering, Guangxi University, Nanning 530004, China; \\ zyyang@st.gxu.edu.cn \\ * Correspondence: szhao@ecust.edu.cn; Tel.: +86-021-6425-2922
}

Citation: Bao, B.; Wang, Z.; Thushara, D.; Liyanage, A.; Gunawardena, S.;

Yang, Z.; Zhao, S. Recent Advances in Microfluidics-Based ChromatographyA Mini Review. Separations 2021, 8, 3. https://doi.org/10.3390/separations 8010003

Received: 25 November 2020 Accepted: 28 December 2020 Published: 31 December 2020

Publisher's Note: MDPI stays neutral with regard to jurisdictional clai$\mathrm{ms}$ in published maps and institutional affiliations.

Copyright: (C) 2020 by the authors. Licensee MDPI, Basel, Switzerland. This article is an open access article distributed under the terms and conditions of the Creative Commons Attribution (CC BY) license (https:// creativecommons.org/licenses/by/ $4.0 /)$.

\begin{abstract}
Microfluidics-based liquid chromatography is based on the miniaturization of the different types of liquid chromatography (LC) systems (e.g., affinity, adsorption, size exclusion, ion exchange) on a microchip to perform on-chip separation of different types of analytes. On-chip chromatography finds applications in genomics, proteomics, biomarker discovery, and environmental analysis. Microfluidics-based chromatography has good reproducibility and small sample consumption. However, the on-chip chromatography fabrication techniques are often more challenging to perform than conventional LC column preparation. Different research groups have attempted to develop different techniques to fabricate microfluidics-based LC systems. In this review, we will summarize the recent advances in microfluidics-based chromatography.
\end{abstract}

Keywords: microfluidics; chromatography; on-chip; LC system

\section{Introduction}

Micro total analysis systems ( $\mu$ TAS) have a variety of advantages over large systems, including less sample consumption, rapid analysis speed, and good portability. Miniaturized on chip electrophoresis and liquid chromatography (LC) have been developed for many years and their separation performance has gradually improved. Compared with on-chip electrophoresis, on-chip LC separation shows better reproducibility and robustness $[1,2]$. Therefore, the development of different on-chip LC systems is attracting more interest than ever before. Sample loss is always a major issue in biological sample handling, especially in handling valuable clinical samples (e.g., limited amounts of samples from biopsy). Microfluidics provides integrated platforms allowing online handling and analysis of the biological samples, thus reducing the sample loss. For instance, the cells can be lysed in the micro channel and the specific biomolecules (e.g., DNA, mRNA, metabolites) are then extracted and analyzed on the chip [3-6]. On-chip LC systems can be readily coupled with different types of detection systems, such as mass spectrometry (MS) $[7,8]$, fluorescent microscopy [9], and conductivity detectors [10]. One example is the application of on-chip LC-MS for the proteomic profiling of small amounts of samples [11]. The on-chip LC-MS system offers unique advantages in proteomic profiling compared with conventional methods. Several different types of columns can be easily integrated on the chip to realize online desalting and multidimensional separation [12]. Equipped with a fluorescent microscope, the separation process can be visualized and monitored easily. The microchip LC can be applied not only to biomolecule separation but also to biological particle separation. For instance, a microchip with antibacteria/virus antibody modification can be applied for 
capturing and recognizing bacteria and viruses in biofluids [13]. Exosomes and circulating tumor cells (CTCs) can be also captured in microfluidic devices and used as biomarkers for cancer diagnosis $[14,15]$.

Based on the mechanism of separation, common LC columns can be divided into five classes: affinity-based, adsorption-based [16,17], size-exclusion-based [18], hydrodynamicbased separation, and ion-exchange-based columns. In this review, we will summarize and discuss the recent advances of microfluidic LC columns based on their separation mechanisms. As both size exclusion and hydrodynamic LC separate the analytes according to their sizes, we will combine them in only one paragraph. We will mainly focus on discussing the preparation and the real-world application of the different types of microfluidics-based LC systems. Figure 1 summarizes the types of microfluidics-based LC systems and their main domains of application.

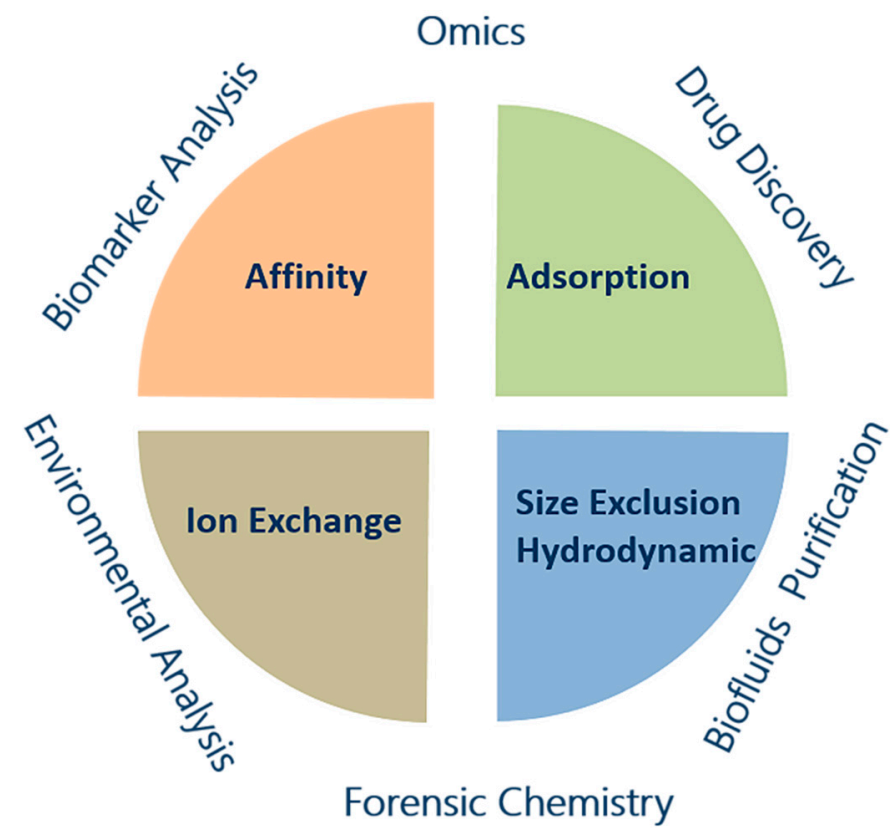

Figure 1. The mechanisms of microfluidics-based liquid chromatography (LC) and their applications.

\section{Affinity-Based Separation}

The definition of affinity interaction is the specific interaction (e.g., coordination, hydrogen bond) between the ligands and biological molecules. Various types of binding ligands can be used for affinity chromatography preparation. Common binding ligands include antibodies, aptamer/oligonucleotides, and metal oxide/metal complexes. Herein, we will summarize the fabrication and applications of on-chip affinity LC systems for complex biological sample analysis.

\subsection{Metal Oxide and Metal Complex}

We will take titanium dioxide $\left(\mathrm{TiO}_{2}\right)$ as an example to discuss the mechanism of oxidized metal ion affinity separation. Titanium dioxide has been widely used for phosphopeptide enrichment in proteomics because of the strong interaction between the $\mathrm{TiO}_{2}$ ligand and phosphor group. The stationary phase is modified with a $\mathrm{TiO}_{2}$ layer, and protein digests are injected into the column with an acidic mobile phase. The interfering peptides or other background compounds are washed away, while the phosphopeptides are retained in the column. The system is then switched into a high $\mathrm{pH}$ condition, and the targeted phosphopeptides are eluted out. This $\mathrm{TiO}_{2}$-based enrichment approach has been widely used in phosphoproteomics. However, sometimes, only limited amounts of clinical samples are available for analysis. A well-known example is the cells obtained from laser capture microdissection (LCM). In LCM, only hundreds of cells can be collected from 
patients for analysis. Analyzing the level of phosphorylation of target proteins in the cells from LCM may provide doctors with important information about cancer progress [19]. Therefore, there is always a strong desire for developing miniaturized metal oxide affinity LC systems. In 2011, Tsougeni et al. [20] reported the fabrication of a $\mathrm{TiO}_{2}-\mathrm{ZrO}_{2}$-based microchip LC system for phosphopeptide analysis. In their method, a simple liquid deposition procedure was performed to generate a thin film of $\mathrm{TiO}_{2}-\mathrm{ZrO}_{2}$ on a polymethyl methacrylate (PMMA) substrate (Figure 2). The authors demonstrated that the micro device could not only separate phosphopeptide standard mixtures (i.e., mono-, tetra-phosphopeptide) but could also analyze the phosphopeptides from protein digests (i.e., $\beta$-Casein digests). MALDI-MS was performed to identify the phosphopeptides eluted from the microchip LC system. This microfluidic affinity chromatography chip had good recovery (94 $\pm 3 \%$ ) and was able to handle small amounts of samples $(<0.1 \mu \mathrm{L})$. The structure of metal oxide film can be tuned to further improve the analysis performance and realize other functions. For instance, Min et al. [21] designed and fabricated $\mathrm{TiO}_{2}$ nanotube arrays and achieved on-chip enrichment and isotope labeling of phosphopeptides. Zhao et al. [22] synthesized and immobilized three-dimensional ordered $\mathrm{TiO}_{2}-\mathrm{ZrO}_{2}$ layers on microfluidic channel walls for enhancing phosphopeptide enrichment efficiency.

1.

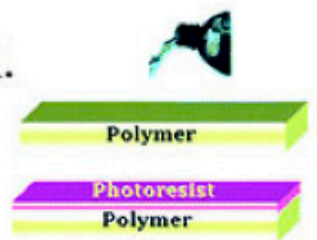

2.

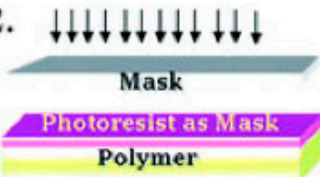

3.

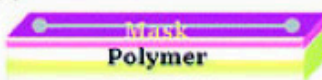

4.

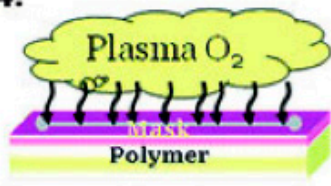

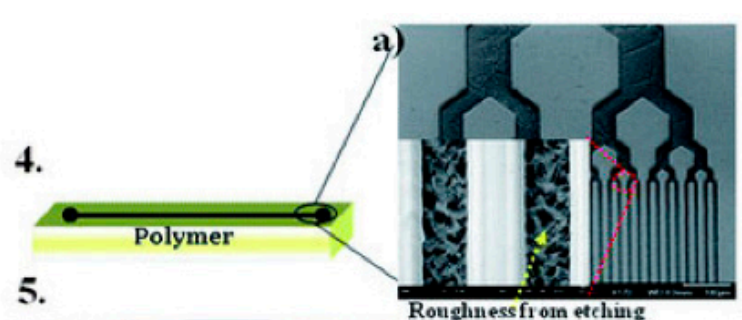

5.

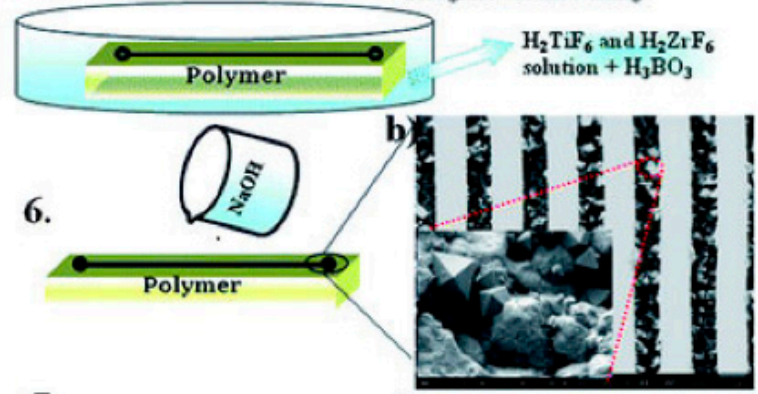

7.

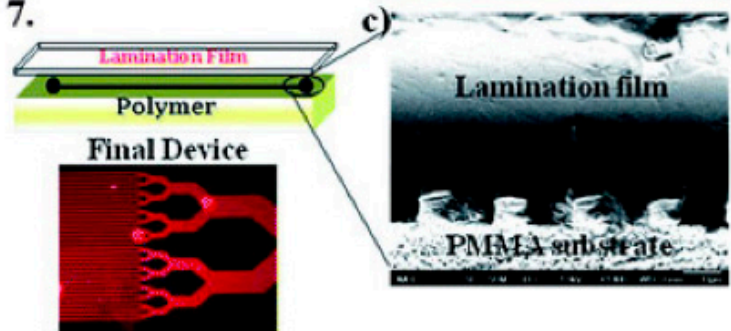

Figure 2. Schematic representation of liquid deposition method for preparing $\mathrm{TiO}_{2}-\mathrm{ZrO}_{2}-$ based microfluidics for phosphopeptide enrichment. 1. Photoresist layer coating on polymethyl methacrylate (PMMA) substrate; 2, 3. Lithography and development of photoresist layer. 4. Plasma etching of PMMA substrate. 5. Liquid deposition of $\mathrm{H}_{2} \mathrm{TiF}_{6}$ and $\mathrm{H}_{2} \mathrm{ZrF}_{6}$ solution. 6. Rinsing with $\mathrm{NaOH}$ and water. 7. Device sealing with lamination film. Reprinted with permission from Tsougeni et al. [20]. Copyright 2011 Royal Society of Chemistry, 2011.

Besides metal oxides, metal complexes represent another important class of ligands applied in affinity separation. A metal complex is formed by the electron donor compounds coordinated to the metal ions. This metal complex ligand can be used for the targeted separation of several specific molecules. In 2012, Lee et al. synthesized zinc-coordinated bis(dipicolylamine) (bis-Zn-DPA)-coated nanoparticles [23] and used them in microflu- 
idic devices to capture bacteria and purify blood. Bis-Zn-DPA-coated nanoparticles can specifically bind with anionic phospholipids on the bacteria membrane, and a magnetic microfluidic system was employed to retain and remove the nanoparticles/bacteria complex. Lee et al. demonstrated the potential use of the system in the process of clearing bacteria and their endotoxins in infectious patients' bloodstreams. By adjusting the metal ions and coordination ligands of the microfluidics-based affinity LC, the capacity for the separation of other types of biological samples is expected.

\subsection{Antibody}

Antibody-based microfluidics has often been studied, due to the specific recognition and interaction between antibody and antigen. The general term "chromatography" refers to the separation of molecules or ions by the interaction between the mobile phase and stationary phase. In the 1970s, Killion et al. defined the term "cell affinity chromatography", which was the technique that could be used to sort the cells based on the interaction between cell surface receptors and an immobilized ligand on a stationary matrix [24].

Antibody-based microfluidics has been employed for separating or analyzing cells, bacteria, and biofluids. One of the well-known applications of antibody-based microfluidics is capturing the circulating tumor cells (CTCs) from cancer patients' blood. Circulating tumor cells are the cells released by the primary tumor and shed into the vasculature. There is some evidence showing the strong correlation between cancer metastasis and circulating tumor cells. Analysis of nucleotides, proteins, or other biomolecules extracted from CTCs can be used for evaluating cancer treatment performance and prognosis. Although only a small number of CTCs exist in cancer patient blood, antibody-based microfluidics may still allow their isolation. Several antibody-antigen-based CTC isolation microfluidics devices have been reported, but there is still room for improving the separation throughput and capture efficiency. For instance, Murlidhar et al. [25] introduced a radial flow technique for isolating CTCs on microchips. Anti-EpCAM (epithelial cell adhesion molecules) antibodies are coated on a chip with specific bean-shaped micro channels (Figure 3). With a radial flow technique, high flow rates $(10 \mathrm{~mL} / \mathrm{h})$ were applied on this system. Compared with conventional CTC capture microfluidic strategies using low flow rates $(1 \mathrm{~mL} / \mathrm{h})$, the throughput of this microchip was enhanced 10-fold. The viability of the cells reached values as high as 93\% even under high flow rates, offering more convenience for downstream analysis.

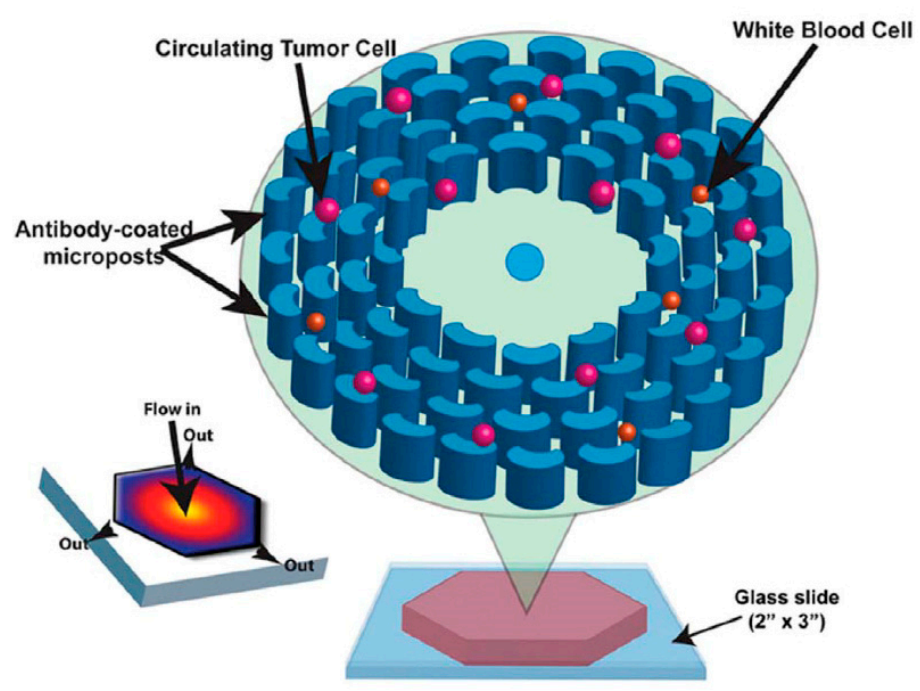

Figure 3. Schematic representation of microfluidics with bean-shaped microposts. The anti-EpCAM (epithelial cell adhesion molecules) antibodies were coated on the surface of bean-shaped microposts. The circulating tumor cells (pink dots) were captured by antibodies. Adapted from Murlidha et al. [25]. Copyright 2014 Wiley Online Library, 2014. 
Antibody-antigen-based microfluidics was also employed for sorting multiple types of cells. Li et al. [26] modified a micro channel with different types of antibodies by integrating a pneumatic actuated control layer and affinity layer, to realize the selective capture of Ramos and HuT 78 cells. Combined with other detection techniques (e.g., PCR, mass spectrometry), the multiple cell-sorting microfluidics can be used for disease diagnosis. Pullagurla et al. [27] reported a microfluidics device which can capture different types of cells for disease diagnosis. In their research, anti-CD4+ and anti-CD66b+ antibodies were immobilized on the micro channel for simultaneously isolating CD4+ T-cells and neutrophils. The mRNA from the cells was extracted and sequenced. The two types of cells can express the stroke-associated genes and thus can be used for stroke diagnosis. The authors demonstrated that the cells isolated from $50 \mu \mathrm{L}$ whole blood could provide enough material for PCR-based sequencing.

Recently, microfluidics devices have been used for analyzing vesicles, including exosomes and ectosomes. Exosomes are extracellular vesicles with diameters of less than $150 \mathrm{~nm}$. Exosomes are released from different types of cells and are involved in intercellular communication; thus, they are considered as a promising type of biomarker for cancer diagnosis. The most common approach for isolating exosomes from patients' blood is high-speed ultracentrifugation. However, expensive high-speed centrifuge equipment is required and this approach is time-consuming $(>10 \mathrm{~h})$ and inefficient. Microfluidics can significantly reduce the time and price of exosome analysis. Chen et al. describe the first reported use of microfluidics for exosome separation and transcriptome analysis [28]. They coated specific exosome-associated antibodies (anti-human CD63) on the chip microchannel. Exosomes were isolated and intravascular RNA was extracted. The high-quality extracted intravascular RNA can be amplified and sequenced by PCR. Therefore, the microfluidicsbased exosome isolation technique can provide valuable information about the genetic status of tumor cells.

Combined with the immunomagnetic bead technique, the efficiency of microfluidicsbased exosome isolation can be further improved. Zhao et al. fabricated a polydimethylsiloxane (PDMS)-based magnetic microchip device which allowed the efficient capture and accurate quantification of exosomes in samples [29]. The magnetic beads and exosomes were well mixed, and the antibody-modified beads captured the exosomes in the samples. The mixtures were then injected into the microfluidics device, the beads were retained by magnetic fields, and the concentrations of captured exosomes were quantified. Compared with conventional exosome quantification methods, a smaller variance in the result was obtained $(\mathrm{CV}<0 \%)$. Due to the continuous-flow design, both small (i.e., $10 \mu \mathrm{L}$ ) and large (i.e., $10 \mathrm{~mL}$ ) volumes of samples can be prepared by the microchip. By multiplexing, it was possible to measure three exosome biomarkers (CA-125, EpCAM, and CD24). The microfluidic system can diagnose ovarian cancer from only $20 \mu \mathrm{L}$ of human plasma. Although the time and sample consumption is significantly reduced, the diagnostic power of the microchip (area under the receiver operator characteristic curve $(\mathrm{AUC})=1.0, p=0.001$ ) is similar to the standard Bradford assay ( $\mathrm{AUC}=1.0, p=0.0009$ ).

He et al. attempted to isolate exosomes and analyze intravascular protein simultaneously by using immunomagnetic bead-based microfluidics [30]. In their work, similar to the previous example, the plasma samples were pre-mixed with antibody-coated magnetic beads and injected into microfluidics. Exosome-bound beads were retained in the micro chamber and washed by phosphate-buffered saline (PBS) for removing blood cells and other matrices. On-bead lysis was performed and lysates were delivered into a second chamber on-chip. In the second micro chamber, the immunomagnetic beads captured the specific protein in lysates and the detection antibodies and chemifluorescence reagent were then introduced into the channel. Figure 4 shows the process of on-chip exosome lysis and protein detection. This approach was able to isolate exosomes from only $30 \mu \mathrm{L}$ plasma samples and quantitatively detect target intravascular proteins. The phosphorylation levels of IGF-1R, which is a promising therapeutic target for non-small-cell lung carcinoma (NSCLC), was successfully determined using this microfluidics device. 


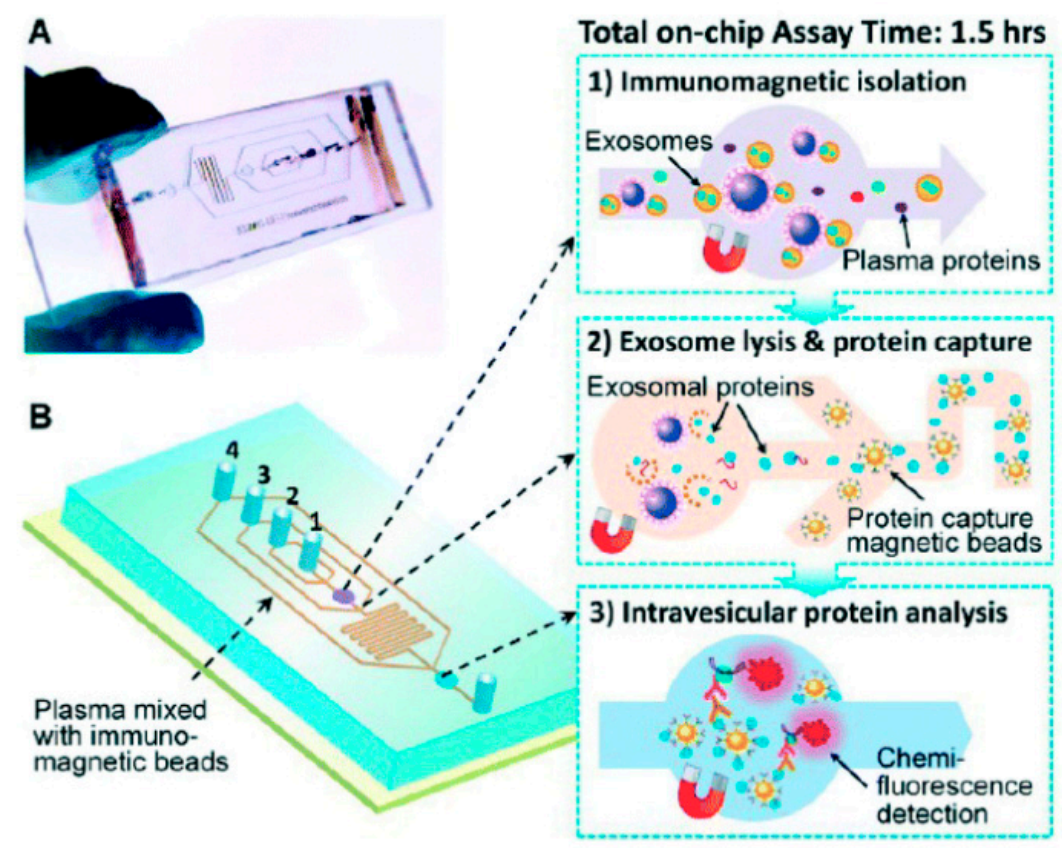

Figure 4. Microfluidic device for exosome capture and intravesicular protein detection. (A). Image of the microfluidic device. (B). Workflow of on-chip exosome analysis. 1. Isolation of exosome-captured magnetic beads from plasma. 2. Exosome lysis and magnetic bead-based protein capture. 3. Protein analysis by chemical fluorescence detection. Reprinted with permission from He et al. [30]. Copyright 2014 Royal Society of Chemistry, 2014.

\subsection{Aptamer}

Aptamer is the oligonucleotide or peptide which can specifically bind with target molecules. Compared with antibodies, the aptamers have their unique advantages. For instance, aptamers are produced in vitro by the systematic evolution of ligands by the exponential enrichment (SELEX) technique, which is different from the antibodies that are produced by in vivo immunizations on animals. Therefore, the time required for the production of aptamers is generally short. Aptamers can bind not only with large molecules but also with small molecules, while the antibody cannot. Based on these advantages, several groups have attempted to develop aptamer-based microchip LC for biomolecule separation.

Reinholt et al. reported the development of a microfluidic device to capture cancer cells and extract and amplify their DNA for gene mutation analysis [31]. In their device, two orthogonal microchannels were fabricated on a PDMS substrate. One channel was for cell capture, and the other one was for DNA analysis. The aptamers were immobilized on the microchannel walls by biotin chemistry. CAOV-3 ovarian cancer cells were injected into the device and lysed by guanidinium isothiocyanate. The released DNA was retained in the microchannel and amplified by isothermal amplification. After sequencing the released DNA from the cancer cells, the authors successfully discovered a mutation point on the TP53 gene. This device can minimize the sample loss during CTC capture and simplify the DNA analysis process. Since many other groups also reported aptamer-based microfluidics for cancer cell analysis, Wu et al. summarized and published a review in 2019 [32]. As mentioned earlier, the aptamers can also bind with specific small-molecule targets. Wang et al. took advantage of this property to fabricate an aptamer-based paper microfluidics device for cocaine detection [33]. In this paper microfluidics device, anti-cocaine aptamers and gold nanoparticles were loaded onto two areas of the paper microfluidics device. After the device is immersed in biofluids, if cocaine is present, it will gradually move to the first area where anti-cocaine aptamers are loaded and bind with them. The cocaine-aptamer complex subsequently moves to the area containing the gold nanoparticles. The nanoparticle 
color will change from red to blue due to the aggregation caused by the cocaine-aptamer complex. The limit of detection by the naked eye can reach values as low as $2.5 \mu \mathrm{g}$.

\section{Adsorption-Based Separation}

In adsorption-based separation processes, the analytes are separated during adsorption and desorption processes, due to their different partition coefficients. Adsorptionbased chromatography, and, in particular, the reversed phase column, is the most widely used chromatography technique for biomolecule analysis. The study of on-chip adsorption based on chip separation started very early. Though a commercialized microchip LC is now available from Agilent and other vendors, optimization of the conditions for separating different samples is still required. For instance, in 2013, Liu et al. reported a nanoLC chip-MS/MS assay for toxin quantification in food [34]. They compared the separation performance of nanoLC chips using different stationary phases (Agilent SB-C18, SB-C8 Zorbax). They also investigated the optimal condition, including microchip LC gradient and multiple reaction monitoring (MRM), for quantification of aflatoxins in peanut products on a reversed phase microchip LC-MS. The presented nanoLC-MS assay has good reproducibility (90.8-100.4\%) and a very low limit of detection $(0.004-0.008 \mathrm{ng} / \mathrm{g})$.

As the etching technology improved, fabricating the microfluidics column with a higher spatial resolution became possible. De Malsche et al. reported the fabrication of pressure-driven nonporous pillar array columns in 2007 [35]. In their approach, UV photolithography and etching silicon oxide were used to fabricate the pillar array. Octyldimethylchlorosilane was flushed into the microchannel and covalently coated on the surface of the pillar array. A mixture of three types of coumarin was injected into the array and a CCD camera was used to monitor the separation process. With $3.5 \mathrm{~mm} / \mathrm{s}$ for the mobile phase velocity, the three coumarin compounds were separated within three seconds. Due to the small resistance of the pillar array column, the Knox's separation impedance (E) also dropped to 150 . E is equal to squared plate height $(\mathrm{H})$ divided by column permeability (K) (i.e., $\mathrm{E}=\mathrm{H}^{2} / \mathrm{K}$ ). E reflects the speed of plate generation and the pressure change during the separation. Columns with good performance always have small $\mathrm{E}$ values. Typical E values of packed columns are around 3000. Later, in 2010, Detobel et al. reported the fabrication of porous-shell pillar array columns [36], for which the micro channel was also fabricated by using UV photolithography. Tetramethoxysilane (TMOS)-based sol-gel procedures were performed to deposit the porous layer on the pillar array and then C8 was coated on the surface. For the porous-shell pillar array column, the minimal plate height was $3.9 \mu \mathrm{m}$ under non-retaining conditions and was $6.9 \mu \mathrm{m}$ when the retention factor was 6.5. The column permeability was lower than theoretical values. The authors further increased the number of theoretical plates of the column by optimizing the pillar design [37]. The optimal column length and pillar diameter were determined by minimalizing the Van Deemter curve and maximal allowable system pressure. From the calculations, the optimal pillar diameter was $\sim 5 \mu \mathrm{m}$ and the column length should be around $3 \mathrm{~m}$. The authors used a similar fabrication method to pattern the pillar assay column. The micro channels with pillars were connected with 10- $\mu \mathrm{m}$-wide turns to increase the column length to $3 \mathrm{~m}$. The measured plate number of this micro array column was approximately 1 million, but the elution time, however, can be significantly reduced compared with conventional packed bed columns.

Lavrik et al. utilized plasma-enhanced chemical vapor deposition (PECVD) to fabricate an enclosed, highly ordered pillar array column [38,39]. The pillar array column manufactured by this approach had better mechanical robustness. In 2016, they further developed their column and demonstrated two-dimensional separation [40]. The pillar array used in this case was modified by $\mathrm{C} 4$ or $\mathrm{C} 18$. A mixture containing six components of 7-chlor-4-nitrobenzofurazan-derivitized amines (NBD-amines) was loaded onto the 2D pillar array system for evaluating the separation performance. The mixtures were separated in the first dimension by using $40 \%$ ethanol/water as the mobile phase. The array was then dried and rotated, and the second-dimension separation was carried out 
with $40 \%$ ethanol/water with $\mathrm{AgNO}_{3}$ added. Olefins can form a complex with $\mathrm{Ag}$ ions, thus reducing their retention capability and offering a different separation mechanism. The co-eluted compound, NBD-hexylamine and NBD-1-amino-5-hexene, on first-dimension separation, could be separated on the second dimension.

The open tubular column is the early equivalent of on-chip LC columns. However, the application of a on-chip tubular column is hampered due to its limited column capacity. Though packed columns have much better capacity and separation efficiency, they are difficult to fabricate on-chip. Therefore, monolithic columns have gradually gained in popularity in microfluidics-based chromatography, since they can be readily fabricated by in situ preparation. In 2008, Levkin et al. reported the preparation of a monolithic porous polymer LC microchip for protein and peptide analysis [41]. Two types of stationary phase were prepared in their research. A methacrylate-based stationary phase was prepared by thermally initiated polymerization of a mixture of lauryl methacrylate and ethylene dimethacrylate, and a styrene-based stationary phase was prepared by polymerization of a mixture of styrene and divinylbenzene. Azobisisobutyronitrile (AIBN) was used as the initiator for polymerization. The microchips were then tested for separating the mixtures of ribonuclease $\mathrm{A}$, myoglobin, cytochrome $\mathrm{C}$, and ovalbumin. The baseline separation was achieved on this styrene-based monolithic column and the separation time was less than $2.5 \mathrm{~min}$. The performance of separating mixtures of peptides was also evaluated.

Tuning the chemistry of the stationary phase enables the monolithic microchip LC to separate not only proteins but also small molecules (e.g., metabolites). In 2018, Kim et al. reported an approach to fabricate a poly(methyl acrylate)-coated monolithic microchip column [42]. Polymerization was initialized by UV light and the monolithic poly(methyl acrylate)-based stationary phase was prepared in a thermoplastic elastomer (TPE) micro channel. Detailed information of the fabrication process is shown in Figure 5. The column back pressure and permeability were measured at different flow rates. Separation of two neurotransmitters (5-hydroxyindole-3-acetic acid (5-HIAA), 5-hydroxytryptamine (serotonin, 5-HT) was demonstrated. Compared with conventional LC systems, the on-chip LC system has another advantage: different columns can be integrated into one chip and achieve high-efficiency separation. In 2005, Yin et al. reported the integration of a sample enrichment column, an analytical column, and a nanospray tip on the same microfluidic chip [43]. The sample enrichment channel was packed with 5- $\mu \mathrm{m}$ particles ZORBAX 300SB-C18, and the analytical channel was packed with the same stationary phase but using smaller size particles (3.5- $\mu \mathrm{m}$ particles). Protein digests were well separated on the chip, with flow rates between 100 and $400 \mathrm{~nL} / \mathrm{min}$. The good robustness of this integrated microchip in high-performance proteomics was also validated. Recently, De Vos et al. developed a novel modulator microchip to realize the heart-cut 2D LC-MS for proteomic analysis [44]. The modulator microchip was fabricated in cyclic olefin copolymer (COC) layers with an additional polyether ether ketone (PEEK) layer protection. The total micro channel volume was $625 \mathrm{~nL}$. The strong cation exchange column was connected with a reversed phase nanocolumn via the modulator microchip. The authors demonstrated that the system could achieve robust analysis under ultra-high pressure (up to $65 \mathrm{MPa}$ ). To evaluate the separation performance, Glu-1-Fibrinopeptide B-spiked bovine serum albumin (BSA) digests were injected onto the LC-MS and their signature peptide was monitored. Without a strong cation column, the signature peptide could not separate with BSA digests on the nano C18 column, while baseline separation was obtained on the 2D-LC system equipped with the modulator microchip interface. 

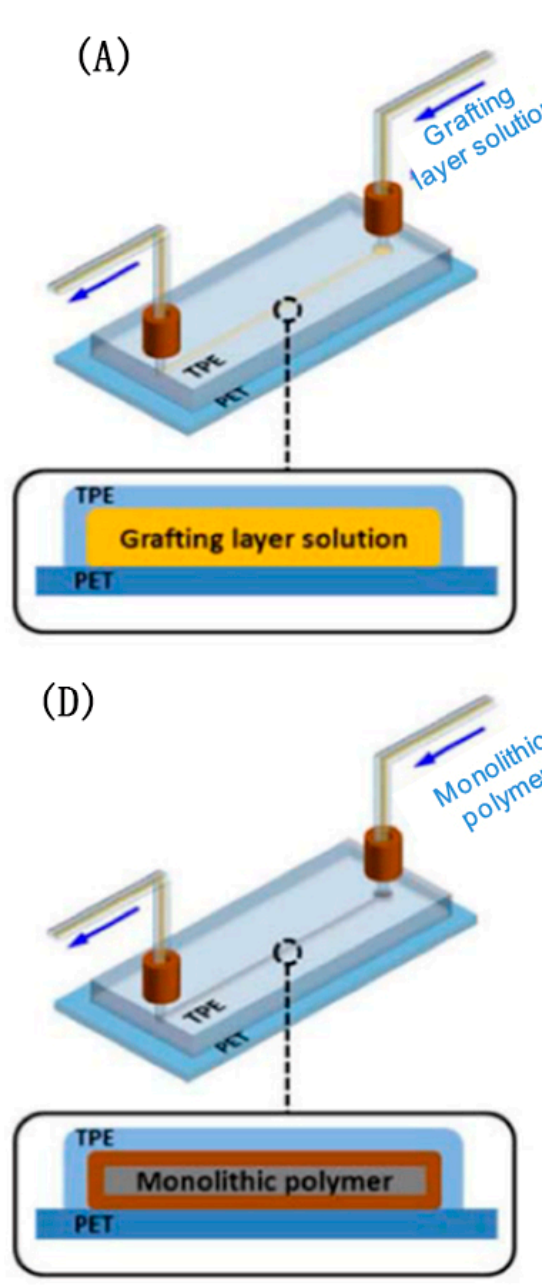
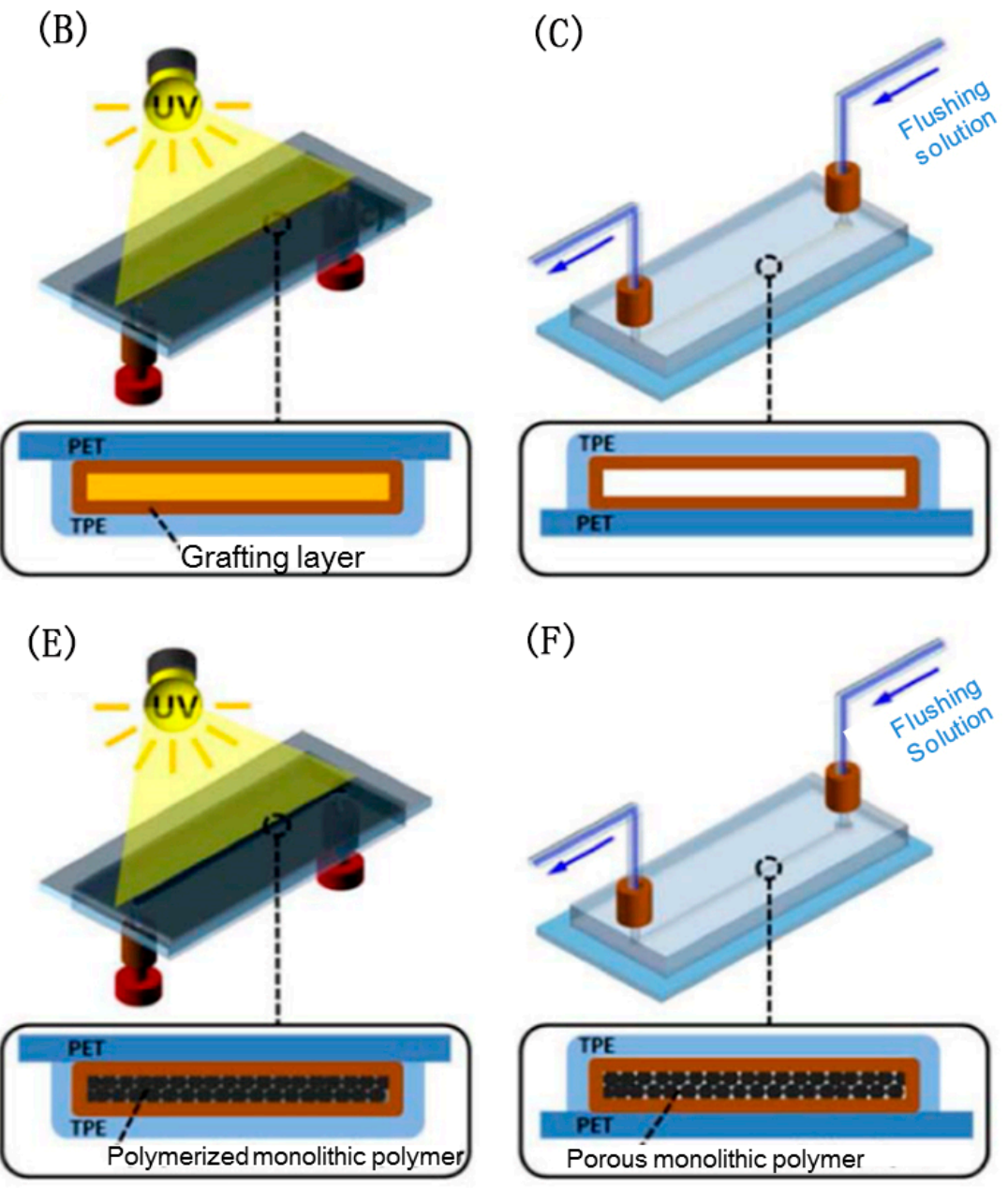

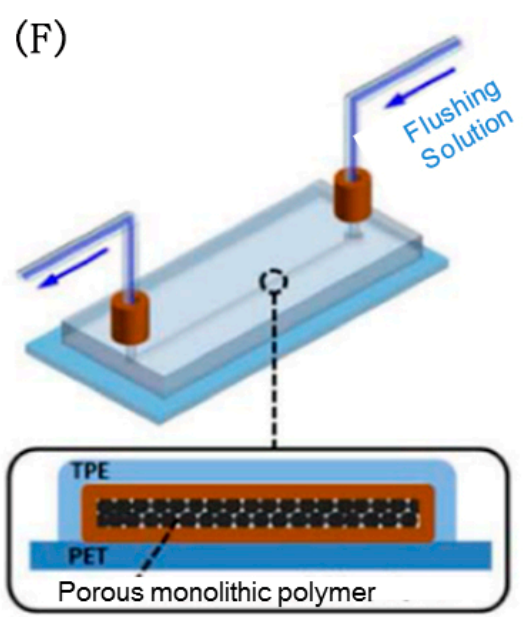

Figure 5. Schematic representation of the fabrication process of monolithic on-chip liquid chromatography. (A) Flushing of the grafting layer solution into micro channel; (B) UV light initialized polymerization to prepare grafting layer; (C) Cleaning of the grafting layer by water/methanol solution; (D,E) Fabrication of nano-porous monolithic polymer by UV initialized polymerization; (F) Cleaning of the reagent residuals. Reprinted with permission from Kim et al. [42]. Copyright 2018 Springer, 2018.

\section{Size Exclusion and Hydrodynamic-Based Separation}

Size exclusion separation chromatography is a method for separating the analytes based on their sizes. Size exclusion separation chromatography is widely used for removing salts in protein purification. Size exclusion chromatography can be also applied in measuring the weight distribution of polymers. The size exclusion chromatography column is usually packed with porous beads. The large molecules will elute out after loading into the column, while the small molecules will enter into the pores and be retained for a longer time and thus will elute out later. Similarly, hydrodynamic chromatography also separates the analytes based on their sizes. However, the separation mechanism of hydrodynamic chromatography is different. The common hydrodynamic chromatography columns are open tubular or packed with non-porous beads. The hydrodynamic separation is based on the parabolic profile flow in the channel. The large particles remain in the middle of the parabolic profile where the flow is faster, and smaller particles move close to the wall of the channel where the flow is slower. Figure 6 shows the profile of the mobile phase flow during hydrodynamic-based separation. Multiple types of detectors (e.g., multiple angle light scattering detector, quasi-elastic light scattering, differential viscometry) can be coupled with hydrodynamic chromatography for determining the size, mass, and shape of the analytes. 
(A)

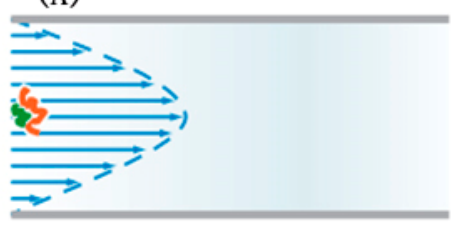

(B)

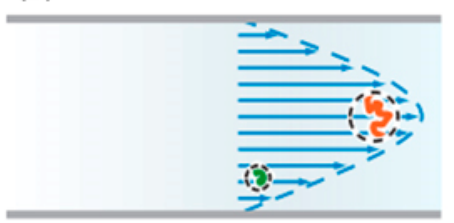

(C)

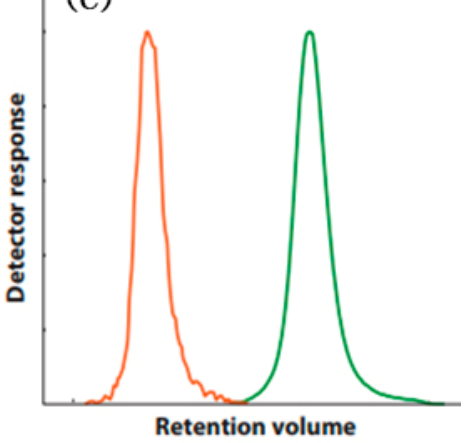

Figure 6. Separation mechanism of hydrodynamic chromatography. (A) A parabolic profile forms during the separation process; (B) The large-sized analyte locates at the center of profile, and the small-sized analyte stays close to the wall of the channel; (C) Chromatographic peaks of large- and small-sized analytes. Adapted from Striegel et al. [45] Copyright 2012 Annual Reviews 2012.

The development of robust on-chip size exclusion or hydrodynamic chromatography systems is challenging, but there are still some excellent works reported. Millet et al. made significant contributions in miniaturizing and integrating the size exclusion and other types of columns on chips. In 2015, they reported a microfluidic system integrating size exclusion, ion exchange, and affinity interaction chromatography [46]. The novel 3D fluidic bridges designed enabled connections between different chromatography modules. The authors demonstrated that the integrated on-chip system could enrich green fluorescent protein (eGFP) from E. coli.

In 2017, Duan et al. reported the development of microfluidics-based hydrodynamic chromatography for DNA analysis [47]. In their design, the nano-capillaries were fabricated on a substrate by glass deposition with the thermo-annealing approach. The inner radius of the fabricated nano-capillaries was approximately $600 \mathrm{~nm}$. Six DNA fragment mixtures, with length between $\sim 3000$ to $\sim 20000 \mathrm{bp}$, were injected into the capillaries for analysis. The separation process was monitored by an epifluorescence microscope. By adjusting the pressure, DNA fragment separation was achieved within $280 \mathrm{~s}$. Most of the fragments were resolved on the chromatogram, except the fragments of $5.8 \mathrm{k}$ and $5.6 \mathrm{kbp}$. The author also demonstrated that the microchip was able to resolve the DNA fragments if their size difference was larger than $1.6 \mathrm{~kb}$.

\section{Ion-Based Separation}

Ion or ion exchange chromatography is a type of chromatography that can separate different ionic species (cations or anions). Ion chromatography has many applications in environmental analysis, especially to monitor the concentrations of different types of ions (e.g., $\mathrm{NO}_{3}{ }^{-}, \mathrm{PO}_{4}{ }^{3-}$ ) in wastewater. Recently, ion chromatography was also applied to the analysis of biomolecules, such as proteins and metabolites. However, compared with affinity or adsorption-based separation, only a few on-chip ion chromatography-associated devices were reported, but ion chromatography is still an important complementary technique for separating unique samples. Several examples will be given and discussed below.

Murrihy et al. fabricated the first on-chip microfluidics ion exchange LC device [48]. In 2001, they demonstrated that the traditional latex nanoparticle-coating approach can also be used for on-chip ion chromatography fabrication. In their microfluidic device, the narrow micro channel $(0.5-10 \mu \mathrm{m})$ enables more interaction between the stationary phase and analytes. They employed this device to separate nitrite, nitrate, and iodide by using $\mathrm{KCl}$ as the mobile phase. The device was equipped with an UV detector. By optimizing the device and separation conditions, the three ions were separated on the chip within $3 \mathrm{~min}$. The linearity of the detection of $\mathrm{NO}_{2}{ }^{-}$and $\mathrm{NO}_{3}{ }^{-}$was between $5 \mu \mathrm{M}$ and $1 \mathrm{mM}$, and the limit of detection was found to be $0.5 \mu \mathrm{M}$. 
In 2012, Niimi et al. performed on-chip chromatography using a hydroxyapatitepacked column for separating and purifying Newcastle Disease Virus (NDV) [49]. First, $40 \mu \mathrm{m}$ ceramic hydroxyapatite particles were packed into the micro channel. To evaluate the performance of the column, NDV was suspended in 5\% fetal bovine serum (FBS) solution and introduced into the microchip. The viruses were captured by hydroxyapatite particles while the FBS proteins and other matrices were eluted out. After this, phosphate buffer was introduced into the system and the viruses were eluted out from the column. In 2014, they further optimized the hydroxyapatite-based microfluidics device, allowing virus diagnosis [50]. Similar hydroxyapatite-based microfluidics was utilized to detect viruses by recognizing viral ribonucleoproteins (RNPs). In this study, after the viruses were captured by hydroxyapatite particles, RNPs were released from the viruses by introducing lysis buffer into the micro channel. RNPs were then introduced to a detection port coated by peptide nucleic acids (PNA). PNA can only capture the specific RNPS; thus, other interferences are washed away with buffer. Finally, horseradish peroxidase (HRP) and luminol were added into the detection port and the color was used to indicate the viruses' presence.

With the growing demand for point-of-care devices, researchers are attempting to develop low-cost microfluidics, such as microfluidic paper analytical devices ( $\mu$ PADs). Instead of fabricating micro channels on plastic substrates, the channel width of $\mu$ PADs is defined by the gap between hydrophobic materials (e.g., wax), and syringe pumps are replaced by cellulose that moves the liquids by capillarity from the inlet to the detection ports. The detection of paper-based microfluidics is usually based on the colorimetric reaction between the targeted analytes and reagent. However, achieving a good quantification accuracy of $\mu$ PADs is always a challenging task. The formed colored product may be washed away, due to the weak interaction between cellulose and the colorimetric reagent. To improve the quantification accuracy of $\mu$ PADs, Rahbar et al. reported the development of ion-exchange (IE)-based $\mu$ PADs to quantify the concentration of different types of ions in serum and wine [51]. Instead of using cellulose, the anion exchange paper was used to fabricate $\mu$ PADs. Fluorescein, as an anion, was used to compare the performance of filter paper versus IE paper. The fluorescein spot was easily washed away by water on filter-based $\mu \mathrm{PAD}$. The fluorescein spot was strongly retained on IE paper when washing using water, but a $\mathrm{NaCl}$ solution could wash the fluorescein spot away, and the distance by which the fluorescein spot moves away depends on the ionic strength of the $\mathrm{NaCl}$ solution. Figure 7 shows the relationship between the fluorescein moving distance and the chloride concentration. The authors employed the IE-based $\mu$ PAD for the determination of the total calcium and total acidity of biological samples. The cation exchange paper was also utilized to fabricate $\mu$ PADs. Murphy et al. [52] evaluated different ion exchange papers and utilized Whatman grade P81 strong cation exchange paper to separate ascorbic acid (AA) and dopamine hydrochloride (DA) on $\mu$ PAD. This $\mu$ PAD was coupled with an electrochemistry detection system and the detection limit for dopamine was as low as $3.41 \mu \mathrm{M}$. 


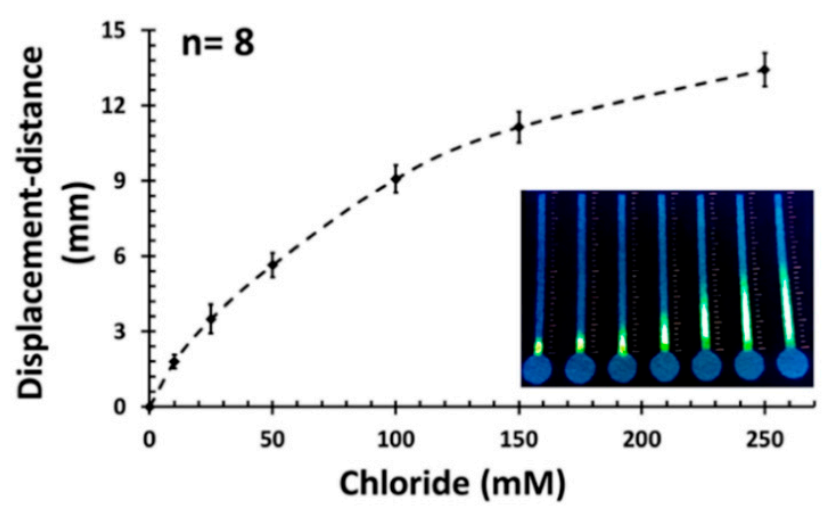

Figure 7. The relationship of fluorescent spot moving distance and the concentration of chloride microfluidic paper analytical devices. Adapted from Rahbar et al. [51]. Copyright 2019 American Chemical Society, 2019.

\section{Other Separation Mechanisms}

Besides the mechanisms mentioned previously, some unique separation mechanisms have also been utilized for on-chip separation. For instance, Kato et al. developed an extended nanospace channel $(10 \sim 100 \mathrm{~nm})$ for attoliter scale sample analysis [53]. Electronbeam lithography was performed to fabricate the extended nanospace channels on quartz glass substrates. They systematically investigated the electric double layer and channel size effect on the separation performance. The electric double layer will be built up near the extended nanospace channel wall when the liquid passes through the channel. The analytes cannot pass through the electric double layer-they can only pass through the center of the channel. Therefore, the larger electric double layer length results in a smaller channel size, and vice versa (Figure 8). Similarly to hydrodynamic chromatography, the flow has a parabolic profile in the extended nanospace channel. The large electric double layer will localize all the charged species in the center of the profile and separation cannot be obtained. If the double layer is too small, the analytes will be spread due to the larger channel size and will cause no velocity difference. Only when the suitable electric double layer length and channel size are well tuned, the species with different charges are able to localize in the different positions of the profile and thus cause separation. Finally, the authors successfully separated fluorescein and sulforhodamine B by using an extended nanospace channel LC within $30 \mathrm{~s}$, and the sample volume was reduced to $280 \mathrm{aL}$. Due to the difficulty of handling such small volumes of samples, in 2011, Ishibashi et al. developed an automated injection system to precisely control the injection time and volume [54]. The injection system can handle sample volumes as small as $550 \mathrm{aL}$. By integrating this injection system with the extended nanospace channel device, they further explored the normal phase separation mode [55]. Toluene was used as the mobile phase to minimize the charge effect used in a previous study. The authors separated the mixture of Pyrromethene 597 and Coumarin 460 within $5 \mathrm{~s}$ under normal phase separation mode. The measured theoretical plate number was 440,000 per meter, and this high separation efficiency is mainly due to the small size effect. The rapid separation process also minimized the sample diffusion. In 2016, Shimizu et al. further increased the separation efficiency by elongating the nano channel [56]. The plate number of the extended nanospace channel could reach up to $1.4 \times 10^{4}$ in this study. To separate more complex samples, gradient elution is always required in liquid chromatography. However, it is usually very challenging to realize onchip gradient separation when the channel size becomes very small. In 2016, Smirnova et al. developed a T-nanomixer to achieve on-chip step mixing for gradient separation [57]. Two channels were fabricated on the T-nanomixer. The first mobile phase was pumped into Channel 1, while the second mobile phase was pumped into Channel 2. The step gradient mixing was realized by adjusting the time of the flow from Channels 1 and 2. A 
mixture containing 17 amino acids was separated within $50 \mathrm{~s}$ and the plate height of most chromatographic peaks was less than $1 \mu \mathrm{m}$.

(A)

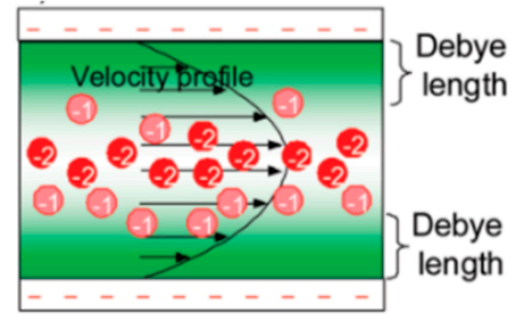

(B)

Large Debye length (Small channel size)

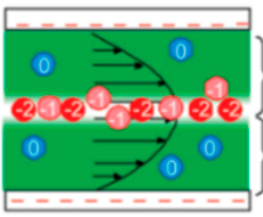

(C)

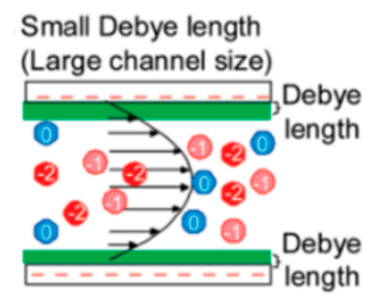

Figure 8. Separation mechanism of extended nanospace channel. (A) Double electric layers built up when flow passed through the nanospace channel. (B) Large Debye length results in small channel size, all the analytes locate at the center of the profile and the separation cannot happen. (C) Small Debye length results in large channel size and the analytes spread in the nanospace channel. Adapted from Kato et al. [50]. Copyright 2010 American Chemical Society, 2010.

The recent advances in microfluidics-based chromatography separation mechanisms are systematically summarized in Table 1, in terms of the chip substrate, fabrication method, stationary phase, mobile phase or carrier fluids, and analytes. Such information is expected to provide useful and updated insights to researchers in the field of microfluidics-based chromatography techniques.

Overall, the major substrates used in on-chip LC systems were polymers and glasses. Papers were also used as a novel type of substrates. Most of the on-chip LC systems were fabricated by lithography combined with plasma etching or PECVD, and paper-based microfluidic devices were fabricated by wax printing. For affinity chromatography, the stationary phases could be immobilized in microfluidic devices by affinity interaction or biotin chemistry. The stationary phases were usually immobilized via covalent bonds in adsorption on-chip LC systems. A variety of other fabrication approaches were also used and summarized in Table 1.

On-chip affinity chromatography is the most powerful system for cell capture and analysis. Other than this, metal-oxide-based affinity chromatography can be used for enriching phosphorpeptides. Adsorption LC systems have wide application in analyzing both small molecules and peptides. Large molecules, such as proteins and DNA, are always separated by using size exclusion or hydrodynamic chromatography. Ion chromatography is the best choice for inorganic ion analysis. Compared with conventional LC systems, the on-chip LC systems can handle small amounts of samples. Coupled with suitable detectors (e.g., MS equipped with nano ion source, fluorescent detectors), the detection sensitivity will be significantly enhanced. The analysis time of on-chip LC systems is also much shorter than the conventional LC system. Due to the shorter plate height and larger plate number, the on-chip LC system enables the separation of complex mixtures within seconds, while similar separation may take several minutes or longer in the conventional LC system. 
Table 1. A summary of microfluidics-based chromatography separation mechanisms.

\begin{tabular}{|c|c|c|c|c|c|c|}
\hline $\begin{array}{l}\text { Separation } \\
\text { Mechanism }\end{array}$ & Chip Substrate & Fabrication Method & Stationary Phase & Mobile Phase or Carrier Fluids & Analytes & Ref \\
\hline \multirow{11}{*}{ Affinity } & PMMA & $\begin{array}{l}\text { Lithographic exposures, plasma } \\
\text { processes }\end{array}$ & $\mathrm{TiO}_{2}-\mathrm{ZrO}_{2}$ & $\begin{array}{c}\text { Acidic mobile phase: FA } 1 \% \\
(v / v), \text { TFA } 0.05 \%(v / v) \\
\text { Basic mobile phase: } \mathrm{NH}_{4} \mathrm{OH}\end{array}$ & Phosphopeptides & {$[20]$} \\
\hline & PDMS, glass & $\begin{array}{l}\text { Photolithographic, wet etching, } \\
\text { soft lithography, replica molding }\end{array}$ & $\mathrm{TiO}_{2}$ nanotube array & $\begin{array}{l}\text { Loading buffer consisting of } 6 \% \\
(v / v) \text { TFA and } 50 \%(v / v) \text { ACN }\end{array}$ & Phosphopeptides & {$[21]$} \\
\hline & PDMS, glass, PMMA & $\begin{array}{c}\text { Emulsifier-free emulsion } \\
\text { polymerization, } \\
\text { evaporation-induced } \\
\text { self-assembly, replica molding }\end{array}$ & $\mathrm{TiO}_{2}-\mathrm{ZrO}_{2}$ film & $\begin{array}{c}\text { Loading buffer: } 50 \% \mathrm{ACN} \text { and } \\
1 \% \mathrm{TFA}\end{array}$ & Phosphopeptides & {$[22]$} \\
\hline & & & $\begin{array}{l}\text { MNPs modified with } \\
\text { bis-Zn-DPA }\end{array}$ & Diluted RBC solution & Escherichia coli & {$[23]$} \\
\hline & PDMS, glass & & Anti-EpCAM & $\begin{array}{l}\text { Healthy blood or serum } \\
\text { free medium }\end{array}$ & Circulating tumor cells & [25] \\
\hline & PDMS, glass & Soft lithography, plasma bonding & Anti-CD4, anti-CD19, etc & Blood & Ramos and HuT 78 cells & [26] \\
\hline & PDMS & Oxygen plasma & Anti-CD63 IgG, anti-CD4 & Serum, blood & Microvesicles & [28] \\
\hline & PDMS, glass & Soft lithography & Immunomagnet-ic beads & Plasma & Exosomes & [29] \\
\hline & PDMS & & $\begin{array}{c}\text { Magnetic beads } \\
\text { conjugated with antibodies }\end{array}$ & Plasma & Tumor exosomes & [30] \\
\hline & PDMS, glass & Soft lithography & DNA aptamers & $\begin{array}{c}\text { PBS binding buffer, } \\
6 \mathrm{M} \text { guanidinium isothiocyanate }\end{array}$ & Cancer cells & [31] \\
\hline & Chromatographic paper & Wax-printing & Anti-cocaine aptamers & $\begin{array}{c}2.8 \mathrm{M} \mathrm{MgCl}_{2} \text { and } 50 \mathrm{mg} / \mathrm{mL} \\
\text { sucrose }\end{array}$ & Cocaine & [33] \\
\hline Adsorption & $\begin{array}{l}\text { NanoLC } \\
\text { chip }\end{array}$ & & SB-C18, SB-C8 Zorbax 300A & $\begin{array}{c}0.5 \mathrm{~g} \mathrm{NaCl} \text { and } 10 \mathrm{~mL} \text { of } 60 \% \\
\mathrm{MeOH}(\mathrm{ag})\end{array}$ & Aflatoxin & [34] \\
\hline
\end{tabular}


Table 1. Cont.

\begin{tabular}{|c|c|c|c|c|c|c|}
\hline $\begin{array}{l}\text { Separation } \\
\text { Mechanism }\end{array}$ & Chip Substrate & Fabrication Method & Stationary Phase & Mobile Phase or Carrier Fluids & Analytes & Ref. \\
\hline \multirow{10}{*}{ Adsorption } & Silicon, glass & $\begin{array}{l}\text { UV photolithography, thermally } \\
\text { (dry) oxidized }\end{array}$ & $\mathrm{C} 8$ & Methanol-water mixture & Coumarin & [35] \\
\hline & Silicon & $\begin{array}{l}\text { UV photolithography, sol-gel } \\
\text { procedures }\end{array}$ & $\mathrm{C} 8$ & Methanol-water mixture & Coumarin & [36] \\
\hline & Silicon & $\begin{array}{l}\text { UV photolithography, dry etching, } \\
\text { reactive ion etching }\end{array}$ & & Methanol-water mixture & Coumarin & [37] \\
\hline & $\begin{array}{l}\text { Silicon, silicon } \\
\text { oxides }\end{array}$ & Photolithography, PECVD & & Methanol-phosphate mixture & $\begin{array}{c}\text { Sulforhodamine B, } \\
\text { fluorescein sodium salt }\end{array}$ & [38] \\
\hline & $\begin{array}{l}\text { Silicon, silicon } \\
\text { oxides }\end{array}$ & Photolithography, PECVD & & $\begin{array}{l}\text { Pure methanol, methanol-water } \\
\text { mixture }\end{array}$ & $\begin{array}{c}\text { Sulforhodamine B, } \\
\text { fluorescein sodium salt }\end{array}$ & [39] \\
\hline & Silicon & UV photolithography, PECVD & $\mathrm{C} 4, \mathrm{C} 18$ & Ethanol-water mixture, $\mathrm{AgNO}_{3}$ & Coumarin, NBD-amines & [40] \\
\hline & Polyimide & Laser ablation & $\begin{array}{l}\text { LaMA-EDMA and ST-DVB } \\
\text { monolith }\end{array}$ & $\begin{array}{c}\text { Acetonitrile } \\
\text { in water (both containing } 0.05 \% \text {, } \\
v / v \text {, formic acid) }\end{array}$ & Proteins and peptides & [41] \\
\hline & TPE, PET, PDMS & Rapid prototyping process & Poly(methyl acrylate) & DI water & Neurotransmitters & [42] \\
\hline & Polyimide & Laser-ablation & Zorbax SB C18 & $\begin{array}{c}\text { Water } \\
\text { with } 0.1 \% \text { formic acid; } 90 \% \\
\text { acetonitrile and } 10 \% \text { water with } \\
0.1 \% \text { formic acid }\end{array}$ & Peptides & [43] \\
\hline & COC, PEEK & $\begin{array}{l}\text { Micromilling, } \\
\text { solvent-vapor-assisted bonding }\end{array}$ & $\mathrm{C} 18$ & & Peptides & [44] \\
\hline \multirow{2}{*}{$\begin{array}{l}\text { Size exclusion and } \\
\text { hydrodynamic }\end{array}$} & PDMS & Photolithography & Sephadex G25 beads & & Proteins & [46] \\
\hline & Glass, $\mathrm{Si}$ & Low-resolution photolithography & & $\begin{array}{c}1 \times \text { TE buffer containing } 10 \mathrm{mM} \\
\text { Tris, and } 1 \mathrm{mM} \text { EDTA }\end{array}$ & DNA & [47] \\
\hline
\end{tabular}


Table 1. Cont.

\begin{tabular}{|c|c|c|c|c|c|c|}
\hline $\begin{array}{l}\text { Separation } \\
\text { Mechanism }\end{array}$ & Chip Substrate & Fabrication Method & Stationary Phase & Mobile Phase or Carrier Fluids & Analytes & Ref. \\
\hline \multirow{4}{*}{ Ion } & Silicon wafer, Pyrex plate & $\begin{array}{l}\text { Photolithography, wet and dry } \\
\text { etching, anodic bonding }\end{array}$ & $\begin{array}{l}\text { Quaternary ammonium latex } \\
\text { particles }\end{array}$ & $\mathrm{KCl}$ solution & $\begin{array}{l}\text { Nitrite, nitrate, iodide, } \\
\text { and thiourea }\end{array}$ & [48] \\
\hline & PDMS & $\begin{array}{c}\text { Replica molding, } \\
\text { photolithography, air plasma }\end{array}$ & Hydroxyapatite & FBS & Virus & [49] \\
\hline & PDMS & $\begin{array}{c}\text { Replica molding, } \\
\text { photolithography, air plasma }\end{array}$ & Hydroxyapatite & FBS & Virus particles & {$[50]$} \\
\hline & $\begin{array}{c}\text { Anion } \\
\text { exchange filter paper }\end{array}$ & Wax printing & Arsenazo III, bromothymol blue & Water & Calcium, tartaric acid & [51] \\
\hline Ion & Cation exchange paper & Wax printing & $\begin{array}{l}\text { Carboxyl groups on the } \\
\text { cellulose paper }\end{array}$ & AA and DA buffer solutions & $\begin{array}{l}\text { Ascorbic acid, dopamine } \\
\text { hydrochloride }\end{array}$ & [52] \\
\hline \multirow{5}{*}{$\begin{array}{l}\text { Other separation } \\
\text { mechanism }\end{array}$} & Glass & $\begin{array}{l}\text { Electron-beam lithography, } \\
\text { plasma etching, thermally } \\
\text { laminated }\end{array}$ & Silanol groups & $0.1 \mathrm{mM}$ phosphate buffer & $\begin{array}{c}\text { Fluorescein, } \\
\text { sulforhodamine B }\end{array}$ & [53] \\
\hline & Glass & $\begin{array}{l}\text { Electron-beam lithography, } \\
\text { plasma etching, thermally } \\
\text { laminated }\end{array}$ & Bare silica (silanol surface) & Toluene-ethanol mixture & Pyrromethene 597 & [54] \\
\hline & Glass & $\begin{array}{l}\text { Electron-beam lithography, } \\
\text { plasma etching, thermally } \\
\text { laminated }\end{array}$ & Bare silica (silanol surface) & Toluene-ethanol mixture & $\begin{array}{l}\text { Pyrromethene } 597, \\
\text { coumarin } 460\end{array}$ & [55] \\
\hline & Fused silica & $\begin{array}{l}\text { Electron beam lithography, } \\
\text { photolithography, reactive ion } \\
\text { etching, thermal fusion bonding }\end{array}$ & Bare silica surface & Hexane-2-propanol mixture & $\begin{array}{l}\text { Pyrromethene 597, } \\
\text { coumarin } 460\end{array}$ & {$[56]$} \\
\hline & Quartz glass & $\begin{array}{l}\text { Electron-beam lithography, } \\
\text { photolithography, plasma etching, } \\
\text { low temperature bonding }\end{array}$ & $\mathrm{C} 18$ & $\begin{array}{c}25 \mathrm{mM} \text { citrate } \\
\text { buffer containing } 25 \mathrm{mM} \\
\text { sodium perchlorate }(\mathrm{pH} 5.5) / \\
\text { acetonitrile }(5-40 \% v / v)\end{array}$ & Amino acids & [57] \\
\hline
\end{tabular}

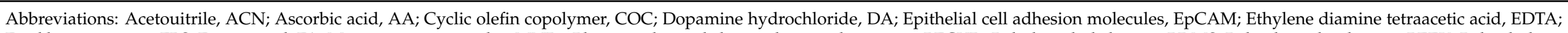

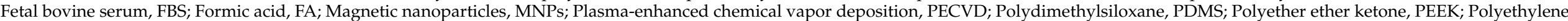

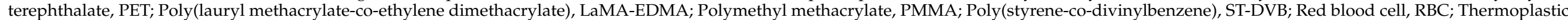
elastomer, TPE; Trifluoroacetic acid, TFA; 7-chlor-4-nitrobenzofurazan-derivitized amines, NBD-amines. 


\section{Conclusions and Outlook}

We reviewed the recent advances in the development of microchip-based LC for biomolecule separation and analysis. Most of the research in the field focuses on affinitybased microchip LC development, as various types of molecules, such as oligonucleotides, peptides, metal complexes, and antibodies, can be used as ligands in affinity-based microchip LC. Affinity-based microchip LC can be applied not only in analyzing biomolecules but also in isolating tumor cells and bacteria. Among all types of microchip LC systems, adsorption-based microchip LC was the system that was commercialized first. Adsorptionbased microchip LC, especially C18-based microchip LC, has been widely employed in proteomics and small molecule analysis. Future work will focus on integrating other types of columns with the reversed phase column on the microchip. Compared with affinity and adsorption-based microchip LC systems, fewer publications are associated with size exclusion and ion exchange microchip LC; this is due to the fact that the fabrication techniques required for their manufacture are more complex and the applications are not as numerous. However, the development of size exclusion and ion exchange microchip LC is still of interest. The integrated size exclusion/reversed phase microchip LC can realize online desalting and thus achieve high-throughput proteomic profiling. Moreover, size exclusion microchips can be potentially used for virus and other small biological particle analysis. Ion exchange microchip LC is a technique essentially used in environmental analysis, as its small size and high portability makes onsite monitoring of multiple types of ions in water possible.

Improving the robustness of microfluidic devices is still an important research area to develop in the future. The lifetime of conventional microflow LC columns can be as long as years and microflow LC columns can usually handle more than 10,000 injections of samples. Unfortunately, we did not see many robustness evaluations of on-chip LC systems in the published works. Although, compared with the conventional LC system, good portability is one of the advantages of on-chip LC systems, the relatively large pumps and difficulty in operation prohibits their application in point-of-care detection. Future work should also consider optimizing the entire systems and making them more user-friendly.

Author Contributions: Conceptualization, B.B.; validation, B.B.; investigation, B.B., Z.W.; resources, Z.W.; data curation, Z.W.; writing-original draft preparation, B.B.; writing-review and editing, B.B., Z.W., A.L., D.T., S.G., Z.Y.; supervision, B.B.; project administration, Shuangliang Zhao; funding acquisition, B.B. All authors have read and agreed to the published version of the manuscript.

Funding: This work is supported by National Natural Science Foundation of China (No. 21808056) and the Shanghai International Science and Technology Collaboration Program (No. 18160743700).

Institutional Review Board Statement: Not applicable.

Informed Consent Statement: Not applicable.

Conflicts of Interest: The authors declare no conflict of interest.

\section{References}

1. Nowak, P.M.; Woźniakiewicz, M.; Gładysz, M.; Janus, M.; Kościelniak, P. Improving repeatability of capillary electrophoresis-A critical comparison of ten different capillary inner surfaces and three criteria of peak identification. Anal. Bioanal. Chem. 2017, 409, 4383-4393. [CrossRef] [PubMed]

2. Schaeper, J.P.; Sepaniak, M.J. Parameters affecting reproducibility in capillary electrophoresis. Electrophoresis 2000, 21, 1421-1429. [CrossRef]

3. Yeh, P.Y.; Rossi, N.A.A.; Kizhakkedathu, J.N.; Chiao, M. A silicone-based microfluidic chip grafted with carboxyl functionalized hyperbranched polyglycerols for selective protein capture. Microfluid. Nanofluid 2010, 9, 199-209. [CrossRef]

4. Benítez, J.J.; Topolancik, J.; Tian, H.C.; Wallin, C.B.; Latulippe, D.R.; Szeto, K.; Murphy, P.J.; Cipriany, B.R.; Levy, S.L.; Soloway, P.D.; et al. Microfluidic extraction, stretching and analysis of human chromosomal DNA from single cells. Lab Chip 2012, 12, 4848-4854. [CrossRef] [PubMed]

5. Sarma, M.; Lee, J.; Ma, S.; Li, S.; Lu, C. A diffusion-based microfluidic device for single-cell RNA-seq. Lab Chip 2019, 19, 1247-1256. [CrossRef] 
6. Feng, D.; Xu, T.; Li, H.; Shi, X.; Xu, G. Single-cell Metabolomics Analysis by Microfluidics and Mass Spectrometry: Recent New Advances. J. Anal. Test. 2020, 4, 198-209. [CrossRef]

7. Mats, L.; Gibson, G.T.T.; Oleschuk, R.D. Plastic LC/MS microchip with an embedded microstructured fibre having the dual role of a frit and a nanoelectrospray emitter. Microfluid. Nanofluid 2014, 16, 73-81. [CrossRef]

8. Wang, X.; Yi, L.; Mukhitov, N.; Schrell, A.M.; Dhumpa, R.; Roper, M.G. Microfluidics-to-mass spectrometry: A review of coupling methods and applications. J. Chromatogr. A 2015, 1382, 98-116. [CrossRef]

9. Lin, S.W.; Chang, C.H.; Lin, C.H. High-throughput Fluorescence Detections in Microfluidic Systems. Genom. Med. Biomark. Health Sci. 2011, 3, 27-38. [CrossRef]

10. Pumera, M. Contactless conductivity detection for microfluidics: Designs and applications. Talanta 2007, 74, 358-364. [CrossRef]

11. Furlan, C.; Dirks, R.A.M.; Thomas, P.C.; Jones, R.C.; Wang, J.; Lynch, M.; Marks, H.; Vermeulen, M. Miniaturised interaction proteomics on a microfluidic platform with ultra-low input requirements. Nat. Commun. 2019, 10, 1-8. [CrossRef] [PubMed]

12. Osiri, J.K.; Shadpour, H.; Witek, M.A.; Steven, S.A. Integrated Multifunctional Microfluidics for Automated Proteome Analyses. Top. Curr. Chem. 2011, 304, 261-294. [CrossRef] [PubMed]

13. Lu, P.H.; Ma, Y.D.; Fu, C.Y.; Lee, G. Bin A structure-free digital microfluidic platform for detection of influenza a virus by using magnetic beads and electromagnetic forces. Lab Chip 2020, 20, 789-797. [CrossRef]

14. Xue, P.; Ye, K.; Gao, J.; Wu, Y.; Guo, J.; Hui, K.M.; Kang, Y. Isolation and elution of Hep3B circulating tumor cells using a dual-functional herringbone chip. Microfluid. Nanofluid 2014, 16, 605-612. [CrossRef]

15. Contreras-Naranjo, J.C.; Wu, H.J.; Ugaz, V.M. Microfluidics for exosome isolation and analysis: Enabling liquid biopsy for personalized medicine. Lab Chip 2017, 17, 3558-3577. [CrossRef]

16. Wali, A.F.; Al Dhaheri, Y.; Pillai, J.R.; Mushtaq, A.; Rao, P.G.M.; Rabbani, S.A.; Firdous, A.; Elshikh, M.S.; Al Farraj, D.A. Lc-ms phytochemical screening, in vitro antioxidant, antimicrobial and anticancer activity of microalgae nannochloropsis oculata extract. Separations 2020, 7, 54. [CrossRef]

17. Song, N.E.; Jung, Y.S.; Choi, J.Y.; Koo, M.; Choi, H.K.; Seo, D.H.; Lim, T.G.; Nam, T.G. Development and application of a multi-residue method to determine pesticides in agricultural water using quechers extraction and lc-ms/ms analysis. Separations 2020, 7, 52. [CrossRef]

18. Oliva, A.; Llabrés, M. Validation of a size-exclusion chromatography method for bevacizumab quantitation in pharmaceutical preparations: Application in a biosimilar study. Separations 2019, 6, 43. [CrossRef]

19. Harsha, H.C.; Pandey, A. Phosphoproteomics in cancer. Mol. Oncol. 2010, 4, 482-495. [CrossRef]

20. Tsougeni, K.; Zerefos, P.; Tserepi, A.; Vlahou, A.; Garbis, S.D.; Gogolides, E. $\mathrm{TiO}_{2}-\mathrm{ZrO}_{2}$ affinity chromatography polymeric microchip for phosphopeptide enrichment and separation. Lab Chip 2011, 11, 3113-3120. [CrossRef]

21. Min, Q.; Chen, X.; Zhang, X.; Zhu, J.J. Tailoring of $\mathrm{a} \mathrm{TiO}_{2}$ nanotube array-integrated portable microdevice for efficient on-chip enrichment and isotope labeling of serum phosphopeptides. Lab Chip 2013, 13, 3853-3861. [CrossRef]

22. Zhao, D.; He, Z.; Wang, G.; Wang, H.; Zhang, Q.; Li, Y. Three-dimensional ordered titanium dioxide-zirconium dioxide film-based microfluidic device for efficient on-chip phosphopeptide enrichment. J. Colloid Interface Sci. 2016, 478, 227-235. [CrossRef] [PubMed]

23. Lee, J.-J.; Jeong, K.J.; Hashimoto, M.; Kwon, A.H.; Rwei, A.; Shankarappa, S.A.; Tsui, J.H.; Kohane, D.S. Synthetic Ligand-Coated Magnetic Nanoparticles for Micro fl uidic Bacterial Separation from Blood. Nano Lett. 2013, 14, 1-5. [CrossRef] [PubMed]

24. Killion, J.J.; Kollmorgen, G.M. Isolation of immunogenic tumour cells by cell-affinity chromatography. Nature 1976, 259, 674-676. [CrossRef] [PubMed]

25. Murlidhar, V.; Zeinali, M.; Grabauskiene, S.; Ghannad-Rezaie, M.; Wicha, M.S.; Simeone, D.M.; Ramnath, N.; Reddy, R.M.; Nagrath, S. A radial flow microfluidic device for ultra-high-throughput affinity-based isolation of circulating tumor cells. Small 2014, 10, 4895-4904. [CrossRef]

26. Li, P.; Gao, Y.; Pappas, D. Multiparameter Cell A ffi nity Chromatography: Separation and Analysis in a Single Micro fl uidic Channel. Anal. Chem. 2012, 84, 8140-8148. [CrossRef]

27. Pullagurla, S.R.; Witek, A.; Jackson, J.M.; Lindell, M.A.M.; Hupert, M.L.; Nesterova, I.V.; Baird, A.E.; Soper, S.A. Parallel A ffi nityBased Isolation of Leukocyte Subsets Using Micro fl uidics: Application for Stroke Diagnosis. Anal. Chem. 2014, 86, 4058-4065. [CrossRef]

28. Chen, C.; Skog, J.; Hsu, C.-H.; Lessard, R.T.; Balaj, L.; Wurdonger, T.; Carter, B.S.; Breakerfiled, X.O.; Toner, M.; Irimia, D. Microfluidic isolation and transcriptome analysis of serum microvesicles. Lab Chip 2010, 10, 505-511. [CrossRef]

29. Zhao, Z.; Yang, Y.; Zeng, Y.; He, M. A microfluidic ExoSearch chip for multiplexed exosome detection towards blood-based ovarian cancer diagnosis. Lab Chip 2016, 16, 489-496. [CrossRef]

30. He, M.; Crow, J.; Roth, M.; Zeng, Y.; Godwin, A.K. Integrated immunoisolation and protein analysis of circulating exosomes using microfluidic technology. Lab Chip 2014, 14, 3773-3780. [CrossRef]

31. Reinholt, S.J.; Craighead, H.G. Microfluidic Device for Aptamer-Based Cancer Cell Capture and Genetic Mutation Detection. Anal. Chem. 2018, 90, 2601-2608. [CrossRef] [PubMed]

32. Wu, L.; Zhu, L.; Huang, M.; Song, J.; Zhang, H.; Song, Y.; Wang, W.; Yang, C. Aptamer-based microfluidics for isolation, release and analysis of circulating tumor cells. TrAC Trends Anal. Chem. 2019, 117, 69-77. [CrossRef]

33. Wang, L.; Musile, G.; McCord, B.R. An aptamer-based paper microfluidic device for the colorimetric determination of cocaine. Electrophoresis 2018, 39, 470-475. [CrossRef] [PubMed] 
34. Liu, H.Y.; Lin, S.L.; Chan, S.A.; Lin, T.Y.; Fuh, M.R. Microfluidic chip-based nano-liquid chromatography tandem mass spectrometry for quantification of aflatoxins in peanut products. Talanta 2013, 113, 76-81. [CrossRef]

35. De Malsche, W.; Eghbali, H.; Clicq, D.; Vangelooven, J.; Gardeniers, H.; Desmet, G. Pressure-driven reverse-phase liquid chromatography separations in ordered nonporous pillar array columns. Anal. Chem. 2007, 79, 5915-5926. [CrossRef]

36. Detobel, F.; De Bruyne, S.; Vangelooven, J.; De Malsche, W.; Aerts, T.; Terryn, H.; Gardeniers, H.; Eeltink, S.; Desmet, G. Fabrication and chromatographic performance of porous-shell pillar-array columns. Anal. Chem. 2010, 82, 7208-7217. [CrossRef]

37. De Malsche, W.; Op De Beeck, J.; De Bruyne, S.; Gardeniers, H.; Desmet, G. Realization of $1 \times 10^{6}$ theoretical plates in liquid chromatography using very long pillar array columns. Anal. Chem. 2012, 84, 1214-1219. [CrossRef]

38. Taylor, L.C.; Lavrik, N.V.; Sepaniak, M.J. High-aspect-ratio, silicon oxide-enclosed pillar structures in microfluidic liquid chromatography. Anal. Chem. 2010, 82, 9549-9556. [CrossRef]

39. Lavrik, N.V.; Taylor, L.C.; Sepaniak, M.J. Enclosed pillar arrays integrated on a fluidic platform for on-chip separations and analysis. Lab Chip 2010, 10, 1086-1094. [CrossRef]

40. Lincoln, D.R.; Lavrik, N.V.; Kravchenko, I.I.; Sepaniak, M.J. Retention in Porous Layer Pillar Array Planar Separation Platforms. Anal. Chem. 2016, 88, 8741-8748. [CrossRef]

41. Levkin, P.A.; Eeltink, S.; Stratton, T.R.; Brennen, R.; Robotti, K.; Yin, H.; Killeen, K.; Svec, F.; Fréchet, J.M.J. Monolithic porous polymer stationary phases in polyimide chips for the fast high-performance liquid chromatography separation of proteins and peptides. J. Chromatogr. A 2008, 1200, 55-61. [CrossRef] [PubMed]

42. Kim, J.; Hare, D.O. Monolithic nano-porous polymer in microfluidic channels for lab-chip liquid chromatography. Nano Converg. 2018, 5, 1-7. [CrossRef] [PubMed]

43. Yin, H.; Killeen, K.; Brennen, R.; Sobek, D.; Werlich, M.; Van De Goor, T. Microfluidic chip for peptide analysis with an integrated HPLC column, sample enrichment column, and nanoelectrospray tip. Anal. Chem. 2005, 77, 527-533. [CrossRef] [PubMed]

44. De Vos, J.; Dams, M.; Broeckhoven, K.; Desmet, G.; Horstkotte, B.; Eeltink, S. Prototyping of a Microfluidic Modulator Chip and Its Application in Heart-Cut Strong-Cation-Exchange-Reversed-Phase Liquid Chromatography Coupled to Nanoelectrospray Mass Spectrometry for Targeted Proteomics. Anal. Chem. 2020, 92, 2388-2392. [CrossRef]

45. Striegel, A.M.; Brewer, A.K. Hydrodynamic chromatography. Annu. Rev. Anal. Chem. 2012, 5, 15-34. [CrossRef]

46. Millet, L.J.; Lucheon, J.D.; Standaert, R.F.; Retterer, S.T.; Doktycz, M.J. Modular microfluidics for point-of-care protein purifications. Lab Chip 2015, 15, 1799-1811. [CrossRef]

47. Duan, L.; Yobas, L. On-chip hydrodynamic chromatography of DNA through centimeters-long glass nanocapillaries. Analyst 2017, 142, 2191-2198. [CrossRef]

48. Murrihy, J.P.; Breadmore, M.C.; Tan, A.; McEnery, M.; Alderman, J.; O'Mathuna, C.; O’Neill, A.P.; O’Brien, P.; Advoldvic, N.; Haddad, P.R.; et al. Ion chromatography on-chip. J. Chromatogr. A 2001, 924, 233-238. [CrossRef]

49. Niimi, M.; Masuda, T.; Kaihatsu, K.; Kato, N.; Arai, F. Virus chromatography; On-chip diagnosis of virus infection from human body fluid. In Proceedings of the 2012 International Symposium on Micro-NanoMechatronics and Human Science, MHS, Nagoya, Japan, 4-7 November 2012; pp. 12-15.

50. Masuda, T.; Niimi, M.; Kaihatsu, K.; Kato, N.; Arai, F. Purification of Virus Particles by Ceramic Hydroxyapatite Chromatography on Microfluidic Chip. In Proceedings of the 14th IEEE International Conference on Nanotechnology, Toronto, ON, Canada, 18-21 August 2014; pp. 131-134.

51. Rahbar, M.; Wheeler, A.R.; Paull, B.; Macka, M. Ion-Exchange Based Immobilization of Chromogenic Reagents on Microfluidic Paper Analytical Devices. Anal. Chem. 2019, 91, 8756-8761. [CrossRef]

52. Murphy, A.; Gorey, B.; De Guzman, K.; Kelly, N.; Nesterenko, E.P.; Morrin, A. Microfluidic paper analytical device for the chromatographic separation of ascorbic acid and dopamine. RSC Adv. 2015, 5, 93162-93169. [CrossRef]

53. Kato, M.; Inaba, M.; Tsukahara, T.; Mawatari, K.; Hibara, A.; Kitamori, T. Femto liquid chromatography with attoliter sample separation in the extended nanospace channel. Anal. Chem. 2010, 82, 543-547. [CrossRef] [PubMed]

54. Ishibashi, R.; Mawatari, K.; Takahashi, K.; Kitamori, T. Development of a pressure-driven injection system for precisely time controlled attoliter sample injection into extended nanochannels. J. Chromatogr. A 2012, 1228, 51-56. [CrossRef] [PubMed]

55. Ishibashi, R.; Mawatari, K.; Kitamori, T. Highly efficient and ultra-small volume separation by pressure-driven liquid chromatography in extended nanochannels. Small 2012, 8, 1237-1242. [CrossRef] [PubMed]

56. Shimizu, H.; Morikawa, K.; Liu, Y.; Smirnova, A.; Mawatari, K.; Kitamori, T. Femtoliter high-performance liquid chromatography using extended-nano channels. Analyst 2016, 141, 6068-6072. [CrossRef] [PubMed]

57. Smirnova, A.; Shimizu, H.; Pihosh, Y.; Mawatari, K.; Kitamori, T. On-Chip Step-Mixing in a T-Nanomixer for Liquid Chromatography in Extended-Nanochannels. Anal. Chem. 2016, 88, 10059-10064. [CrossRef] [PubMed] 